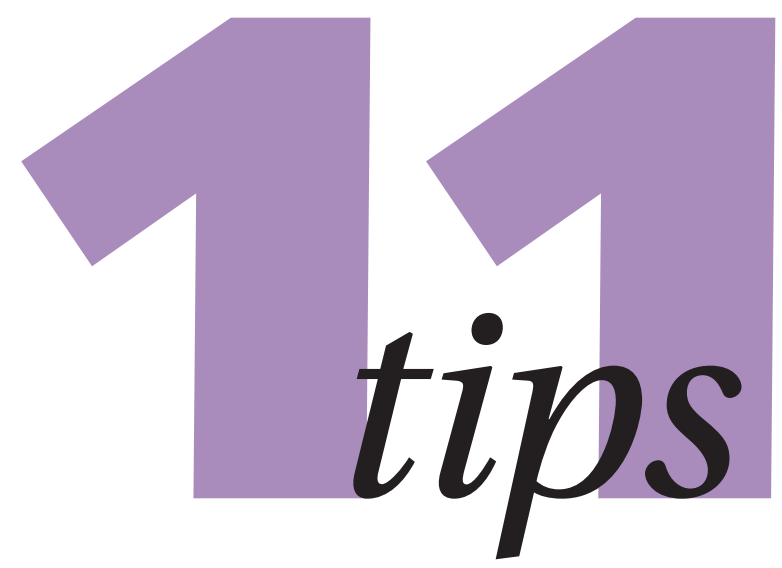

\author{
Vaders worden nog te vaak buiten gesloten \\ bij de opvoeding van hun kinderen. Pro- \\ fessionals, waaronder ook pedagogisch mede- \\ werkers, richten zich tijdens gesprekken of \\ hulpvragen vaak onbewust op de moeders. \\ Onderzoeks- en adviesbureau Sardes maakte \\ een handreiking met tips.
}

TEKST MARIANNE VELSINK

\title{
OM VADERS MEER TE BETREKKEN
}

1 Benadruk bij de kennismaking dat jullie het belangrijk vinden als je ouders samen ziet: moeders en vaders zijn allebei belangrijk voor een kind.

2 Informeer bij de kennismaking naar de achtergrond van beide ouders interesses, baan, hobby's -om hen beter te leren kennen. Dat helpt bij het latere contact.

3 Vraag ouders (en dus ook mannen) elk apart hoe zij willen dat er met hen gecommuniceerd wordt.

Ga ervan uit dat mannen net zoveel bijdragen aan de opvoeding van kinderen als vrouwen. Spreek vaders aan op hun rol: wat kun en wil jij doen?

Loop de teksten op je website eens na: worden daar zowel mannen als vrouwen aangesproken? Zorg dat je niet alleen foto's van vrouwen met kinderen maar ook van mannen met kinderen plaatst.

6 Stimuleer dat beide ouders via Whats- App, Facebook of via de groeps-app communiceren met professionals.

7 Nodig voor tienminutengesprekken nadrukkelijk beide ouders uit of spreek om en om met de vader en de moeder.
Richt je tijdens de formele bespreek- momenten, zoals het tienminutengesprek, tot beide ouders. Soms zetten mannen zichzelf 'buitenspel' en voert vooral de moeder het gesprek.

9 Stap tijdens de dagelijkse brengen haalmomenten op de vaders af. Wacht niet totdat zij jou aanspreken, maar neem zelf het initiatief. Vraag hoe hun dag was en maak een bruggetje naar een pedagogisch gesprek.

10 Betrek mannen bij het bedenken en organiseren van activiteiten op de locatie.

11 Je kunt overwegen om aparte activiteiten voor vaders (en hun kinderen) te organiseren als daar behoefte aan is. Maar ga er niet automatisch van uit dat je mannen beter bereikt met 'mannenactiviteiten. <

MEER WETEN? DOWNLOAD DE GRATIS HANDREIKING 'HOE BETREK JE ALS ORGANISATIE OOK MANNELIJKE OPVOEDERS?' OP WWW.SARDES.NL.

\section{FACTS \& FIGURES}

- $60 \%$ van de mannen zou meer tijd doorbrengen met de kinderen als praktische zaken en kosten geen rol zouden spelen

- De vrije tijd van vrouwen is vaker versnipperd en ze brengen die vaker in aanwezigheid van hun kinderen door dan de vaders.

- Kinderen van betrokken vaders denken minder in genderstereotypen.

- Vaderbetrokkenheid heeft een positief effect op de cognitieve, emotionele, sociale en fysieke ontwikkeling van kinderen. 